\title{
Studying in Dermatology Residency
}

\author{
Sophie A. Greenberg, MD
}

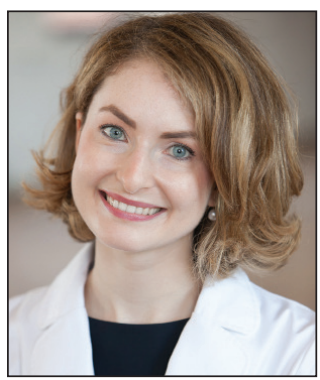

\section{RESIDENT PEARLS}

- Independent study is a large component of dermatology residency.

- Consistent habits and a tailored approach will support optimal learning for each dermatology resident.

- The beginning of residency is a good time to explore a variety of resources to see what works best. Toward the end of residency, as studying becomes more targeted, residents may benefit from sticking to the resources with which they are most comfortable.

Studying during dermatology residency may be overwhelming due to the large amount of material and numerous resources available. This article provides an overview of available resources and a guide on tailoring one's approach to studying throughout residency.

Cutis. 2020;106:E23-E27.

D ermatology residency can feel like drinking from a firehose, in which one is bombarded with so much information that it is impossible to retain any content. This article provides an overview of available resources and a guide on how to tailor studying throughout one's training.

\section{Prior to Residency}

There are several resources that provide an introduction to dermatology and are appropriate for all medical students, regardless of intended specialty. The American Academy of Dermatology offers a free basic dermatology curriculum (https://www.aad.org /member/education/residents/bdc), with a choice of a 2- or 4-week course consisting of modules such as skin examination, basic science of the skin, dermatologic therapies, and specific dermatologic conditions. VisualDx offers LearnDerm (https://www.visualdx.com /learnderm/), which includes a 5-part tutorial and quiz focused on the skin examination, morphology, and lesion distribution. Lookingbill and Marks' Principles of Dermatology ${ }^{1}$ is a book at an appropriate level for a medical student to learn about the fundamentals of dermatology. These resources may be helpful for residents to review immediately before starting dermatology residency (toward the end of intern year for most).

\section{First Year}

During the beginning of dermatology residency (postgraduate year [PGY] 2 for most), the fire hose of information feels most daunting. During this time, studying should focus on engendering a broad overview of dermatology. Most residencies maintain a textbook reading schedule, which provides a framework from which residents may structure their studying. Selection of a textbook tends to be program dependent. Even if the details of reading the textbook do not stick when reading it the first time, benefits include becoming familiar with what information one is expected to learn as a dermatologist and developing a strong foundation upon which one may continue to build. Based on my informal discussions with current residents, some reported that reading the textbook did not work well for them, citing too much minutiae in the textbooks and/or a preference for a more active learning approach. These residents instead focused on reading a review book for a broad overview, accompanied by a textbook or VisualDx when a more detailed reference is necessary. Table 1 provides a list of

From the Department of Dermatology, Columbia University Medical Center, New York, New York.

The author reports no conflict of interest.

Correspondence: Sophie A. Greenberg, MD, 161 Fort Washington Ave, 12th Floor, New York, NY 10032 (sag2203@cumc.columbia.edu). doi: $10.12788 /$ cutis.0082 
textbooks and mobile applications (apps) that residents may find helpful.

First-year residents may begin their efforts in synthesizing this new knowledge base toward the end of the year in preparation for the BASIC examination. The American Board of Dermatology provides a content outline as well as sample questions on their website (https://www.abderm.org/residents-and-fellows/exam -of-the-future-information-center.aspx\#content), which may be used to guide more focused studying efforts during the weeks leading up to the examination.

\section{Second Year}

For second-year residents (PGY-3 for most) studying should focus on deepening and consolidating the broad foundation that was established during their first year. For many, this pursuit involves rereading the textbook chapters alongside more active learning measures, such

\section{TABLE 1. Select Textbooks and Mobile Apps for Dermatology Residents}

\begin{tabular}{|c|c|c|}
\hline Resource & Category & Description \\
\hline Andrews' Diseases of the Skin ${ }^{2}$ & Textbook & Major textbook for dermatologists \\
\hline $\begin{array}{l}\text { Derm In-Review Study Guide } \\
\text { (https://dermatologyinreview.com/lilly/) }\end{array}$ & Review book and e-book & $\begin{array}{l}\text { Available free of charge to } \\
\text { dermatology residents }\end{array}$ \\
\hline $\begin{array}{l}\text { Dermatology (also referred to } \\
\text { as "Bolognia") }\end{array}$ & Textbook & Major textbook for dermatologists \\
\hline $\begin{array}{l}\text { Dermatology: Illustrated Study Guide } \\
\text { and Comprehensive Board Review }\end{array}$ & Review book & cise review book \\
\hline Dermatopathology 5 & Textbook & Basic overview of dermatopathology \\
\hline $\begin{array}{l}\text { Lookingbill and Marks' Principles } \\
\text { of Dermatology }\end{array}$ & Textbook & $\begin{array}{l}\text { Basic overview of dermatology, great } \\
\text { resource for medical students }\end{array}$ \\
\hline Neonatal and Infant Dermatology ${ }^{6}$ & & $\begin{array}{l}\text { Textbook on neonatal and infant } \\
\text { dermatology }\end{array}$ \\
\hline Review of Dermatology ${ }^{7}$ & Rovin & $\begin{array}{l}\text { Detailed overview, bold print of important } \\
\text { boards factoids }\end{array}$ \\
\hline $\begin{array}{l}\text { VisualDx } \\
\text { (https://www.visualdx.com/) }\end{array}$ & app and website & $\begin{array}{l}\text { Check if your institution provides a } \\
\text { subscription }\end{array}$ \\
\hline
\end{tabular}

TABLE 2. Question Banks Available to Dermatology Residents

\begin{tabular}{ll}
\hline Question Bank & Description \\
\hline $\begin{array}{l}\text { AAD Board Prep Plus } \\
\text { (https://www.aad.org/member/education/residents/board-prep) }\end{array}$ & $\begin{array}{l}1000 \text { boards-style questions; subscription cost ranges from } \\
\$ 249 \text { for } 3 \text { months to } \$ 348 \text { for } 12 \text { months }\end{array}$ \\
\hline $\begin{array}{l}\text { Anki } \\
\text { (https://apps.ankiweb.net/) }\end{array}$ & $\begin{array}{l}\text { Free flashcard app; users may quiz themselves using } \\
\text { question banks that have been created by other users, } \\
\text { including dermatology residents }\end{array}$ \\
\hline $\begin{array}{l}\text { Derm In-Review } \\
\text { (https://dermatologyinreview.com/lilly/) }\end{array}$ & $\begin{array}{l}>3000 \text { boards-style questions; bank of }>2100 \text { flashcards, } \\
\text { kodachromes, and study guide; free for dermatology } \\
\text { residents, courtesy of Eli Lilly and Company }\end{array}$ \\
\hline $\begin{array}{l}\text { DermQBank } \\
\text { (www.dermqbank.com) }\end{array}$ & $\begin{array}{l}>2300 \text { boards-style questions; subscription cost is } \$ 249 \text { for } \\
6 \text { months and } \$ 299 \text { for } 12 \text { months }\end{array}$ \\
\hline
\end{tabular}

Abbreviations: AAD, American Academy of Dermatology; app, application. 
as taking notes and quizzing oneself using flashcard apps and question banks (Table 2). Others may benefit from listening to podcasts (Table 3) or other sources utilizing audiovisual content, including attending conferences and other lectures virtually, which is becoming increasingly available in the setting of the coronavirus disease 2019 pandemic (Table 4). Because there are so many resources available to support these efforts, residents should be encouraged to try out a variety to determine what works best.

Toward the end of second year, studying may be tailored to preparing for the CORE examinations using the resources of one's choice. Based on my discussions with current residents, a combination of reading review books, reviewing one's personal notes, and quizzing through question banks and/or flashcard apps could be used.

In addition to maintaining a consistent and organized study schedule, second-year residents should continue to read in depth on topics related to patients for whom they are caring and stay on top of the dermatology literature. Table 5 provides a list of medical journals that dermatology residents should aim to read. The Journal of the American Academy of Dermatology's continuing medical education series (https://www.jaad.org/content/collection-cme) may be particularly helpful to residents. In this series, experts review a variety of dermatologic topics in depth paired with quiz questions.

\section{Third Year}

As a third-year resident (PGY-4 for most), studying should focus on deepening one's knowledge base and beginning preparation for the boards examination. At this point, residents should stick to a limited selection of resources (ie, 1 textbook, 1 review book, 1 question bank) for in-depth study. More time should be spent on active learning, such as note-taking and question banks. Boards review courses historically have been available to dermatology residents, namely the Barron Board Review course and a plenary session at the American Academy of Dermatology Annual Conference (Table 4).

\section{Consistent Habits}

Studying strategies can and should differ throughout dermatology residency, though consistency is necessary throughout. It is helpful to plan study schedules in advance-yearly, monthly, weekly_and aim to stick to

TABLE 3. Select Podcasts for Dermatology Residents

\begin{tabular}{|c|c|}
\hline Podcast & Description \\
\hline $\begin{array}{l}\text { AAD's Dialogues in Dermatology } \\
\text { (https://www.aad.org/member/education/continuing/dialogu }\end{array}$ & $\begin{array}{l}\text { Expert discussion of dermatologic topics, overview of JAAD } \\
\text { issues, and practice trends }\end{array}$ \\
\hline $\begin{array}{l}\text { Dermasphere } \\
\text { (https://dermaspherepodcast.com/) }\end{array}$ & Overview of the latest dermatology research \\
\hline $\begin{array}{l}\text { Dermcast TV } \\
\text { (http://dermcast.tv/audio/) }\end{array}$ & Education for dermatology PAs \\
\hline $\begin{array}{l}\text { JAMA Dermatology Author Interviews } \\
\text { (https://jamanetwork.com/journals/jamadermatology/pages } \\
\text { /jama-dermatology-author-interviews) }\end{array}$ & $\begin{array}{l}\text { Interview of authors regarding their recent publications in } \\
\text { JAMA Dermatology }\end{array}$ \\
\hline $\begin{array}{l}\text { Journal of Drugs in Dermatology Podcast } \\
\text { (https://jddonline.com/category/podcast) }\end{array}$ & $\begin{array}{l}\text { Monthly; featuring interviews with and practical pearls from } \\
\text { the principal investigator of a high-profile manuscript }\end{array}$ \\
\hline $\begin{array}{l}\text { Journal of Investigative Dermatology SkinPod } \\
\text { (https://www.jidonline.org/content/skinpods) }\end{array}$ & $\begin{array}{l}\text { Delves into the latest basic and clinical research in cutaneous } \\
\text { biology and skin disease, featuring highlighted content from } \\
\text { each issue, as well as interviews with leading researchers in } \\
\text { the field }\end{array}$ \\
\hline $\begin{array}{l}\text { LearnDerm podcast } \\
\text { (https://learndermpodcast.com/) }\end{array}$ & $\begin{array}{l}\text { Logan Kolb, DO, a PGY-4 dermatology resident, breaks } \\
\text { down common skin rashes and lesions in a simple, fun, and } \\
\text { engaging fashion to build a strong foundation of dermatology } \\
\text { knowledge for dermatology providers }\end{array}$ \\
\hline $\begin{array}{l}\text { MDedge Dermatology Weekly } \\
\text { (https://www.mdedge.com/podcasts/dermatology-weekly) }\end{array}$ & $\begin{array}{l}\text { Combines the latest news in clinical dermatology with peer-to- } \\
\text { peer interviews with Cutis Editor in Chief Vincent A. DeLeo, MD }\end{array}$ \\
\hline
\end{tabular}

Abbreviations: AAD, American Academy of Dermatology; JAAD, Journal of the American Academy of Dermatology; PA, physician assistant;

PGY, postgraduate year. 
TABLE 4. Select Conferences for Dermatology Residents

\begin{tabular}{|c|c|}
\hline Conference & Description \\
\hline $\begin{array}{l}\text { AAD } \\
\text { (https://www.aad.org/member/meetings-education) }\end{array}$ & $\begin{array}{l}\text { Largest dermatology conference in the United States; } \\
\text { main conference takes place annually in February } \\
\text { or March; a smaller conference occurs annually } \\
\text { in the summer; a virtual meeting experience } \\
\text { (https://www.aad.org/member/meetings-education } \\
\text { /aadvmx) currently is available on the AAD website } \\
\text { through the end of } 2020 \text { ( } \$ 190 \text { for residents) }\end{array}$ \\
\hline $\begin{array}{l}\text { Barron Board Review Course } \\
\text { (http://www.dermpathdiagnostics.com/clinicians/dermpathuniversity } \\
\text { /dermatopathology-reviews-2/barronboardreview/) }\end{array}$ & Offered annuallya \\
\hline $\begin{array}{l}\text { Dermoscopy Intermediate Course } \\
\text { (https://mskcc.cloud-cme.com/course/courseoverview?P=5\&EID =9082) }\end{array}$ & Held annually at MSKCC (New York, New York) \\
\hline $\begin{array}{l}\text { Dermpath Diagnostics Courses } \\
\text { (http://www.dermpathdiagnostics.com/clinicians/dermpathuniversity } \\
\text { /dermatopathology-reviews-2/) }\end{array}$ & $\begin{array}{l}\text { Courses are available throughout the year, now } \\
\text { offered virtually }\end{array}$ \\
\hline $\begin{array}{l}\text { Skin of Color Society Scientific Symposium } \\
\text { (http://skinofcolorsociety.org/16th-annual-socs-scientific } \\
\text {-symposium-virtual-program/) }\end{array}$ & $\begin{array}{l}\text { CME; focuses on the unique needs of Fitzpatrick } \\
\text { skin types III-VI; offering a virtual learning opportunity } \\
\text { (September 12-13, 2020) }\end{array}$ \\
\hline $\begin{array}{l}\text { Society for Pediatric Dermatology } \\
\text { (https://pedsderm.net/meetings/annual-meeting/) }\end{array}$ & d virtually \\
\hline
\end{tabular}

Abbreviations: AAD, American Academy of Dermatology; MSKCC, Memorial Sloan Kettering Cancer Center; CME, continuing medical education.

The 2020 course has been cancelled due to coronavirus disease 2019.

\section{TABLE 5. Medical Journals to Aid Dermatology Residents}

\begin{tabular}{ll}
\hline Journal & About \\
\hline Cutis & $\begin{array}{l}\text { Published since 1965, Cutis is a peer-reviewed clinical journal for the } \\
\text { dermatologist, allergist, and general practitioner; published monthly } \\
\text { and focuses on concise clinical articles that present the practical side } \\
\text { of dermatology }\end{array}$ \\
\hline Dermatologic Surgery & Monthly peer-reviewed journal focusing on dermatologic surgery \\
\hline Journal of the American Academy of Dermatology (JAAD) & $\begin{array}{l}\text { Features monthly CME articles and quizzes as well as latest } \\
\text { dermatology publications; companion journals include JAAD Case } \\
\text { Reports and JAAD International }\end{array}$ \\
\hline JAMA Dermatology & $\begin{array}{l}\text { Monthly peer-reviewed medical journal published by the American } \\
\text { Medical Association; covers the effectiveness of diagnosis and } \\
\text { treatment in medical and surgical dermatology, pediatric and geriatric } \\
\text { dermatology, and oncologic and aesthetic dermatologic surgery }\end{array}$ \\
\hline Journal of Investigative Dermatology & $\begin{array}{l}\text { Peer-reviewed medical dermatology journal } \\
\text { New England Journal of Medicine }\end{array}$ \\
$\begin{array}{l}\text { Weekly medical journal published by the Massachusetts Medical } \\
\text { Society; often covers topics relevant to dermatologists, including its } \\
\text { weekly image challenge }\end{array}$
\end{tabular}

Abbreviation: CME, continuing medical education. 
them as much as possible. Finding what works for each individual may take trial and error. For some, it may mean waking up early to study before work, whereas others may do better in the evenings. It also is helpful to utilize a combination of longer blocks of studying (ie, weekend days), with consistent shorter blocks of time during the week. Many residents also learn to take advantage of time spent commuting by listening to podcasts in the car or reading while on public transportation.

\section{Final Thoughts}

There are many resources available to support residents in their learning such as textbooks, journals, podcasts, flashcards, question banks, and more. The path to mastery will be individualized for each resident, likely using a unique combination of resources. The beginning of residency is a good time to explore a variety of resources to see what works best, whereas at the end studying becomes more targeted.

\section{REFERENCES}

1. Marks Jr JG, Miller JJ. Lookingbill and Marks' Principles of Dermatology. 6th ed. China: Elsevier; 2019.

2. James WD, Elston DM, Treat JR. Andrews' Diseases of the Skin. 13th ed. China: Elsevier; 2019.

3. Bolognia JL, Schaffer JV, Cerroni L, eds. Dermatology. 4th ed. China: Elsevier; 2018.

4. Jain S. Dermatology: Illustrated Study Guide and Comprehensive Board Review. New York, NY: Springer; 2012.

5. Elston DM, Ferringer T, Ko C, et al. Dermatopathology. 2nd ed. China: Elsevier Saunders; 2014.

6. Eichenfield LF, Frieden IJ, eds. Neonatal and Infant Dermatology. London, England: Saunders; 2015.

7. Alikhan A, Hocker TLH, eds. Review of Dermatology. China: Elsevier; 2017. 